\title{
Highly Skilled Migrant Women: A Career Development Framework
}

Mrs Riana van den Bergh (Corresponding author)

PhD Student

Department of Human Resource Management

University of Pretoria, South Africa

Kromme Nieuwegracht 90bis, 3512 HM, Utrecht, The Netherlands

Mobile: +31648156976_E-Mail: rianavandenbergh@yahoo.com

Riana van den Bergh is a $\mathrm{PhD}$ fellow at the University of Pretoria and a consultant/researcher at Trompenaars Hampden-Turner Consulting in Amsterdam. Riana is a Cultural Intelligence expert whose current research focuses on the intercultural adjustment experiences of expatriate women professionals around the world.

\section{Prof. Yvonne du Plessis}

Associate Professor

Department of Human Resource Management

University of Pretoria, South Africa

Economic and Management Sciences Building, Cnr. Lynnwood \& Roper Street, Hatfield, Pretoria, South Africa

Tel: +27124203574 E-Mail:yvonne.duplessis@up.ac.za

Yvonne du Plessis is an Associate Professor in the Department of Human Resource Management, University of Pretoria and has international work experience. She has coauthored several academic books on Management and Project Management and has presented extensively at national and international conferences. She has received numerous awards and research grants, with work published, inter alia, in the South African Journal of Human Resource Management and the Journal of Contemporary Management. Currently, she specialises in contemporary people management aspects in multi-cultural work settings, Applied Organisational Behaviour, International Human Resource Management (expatriation and repatriation) and the people side of Project Management. 


\begin{abstract}
Purpose - This paper aims to explore and interpret the pre-migration and post-migration career development and success of highly skilled professional migrant women with special reference to the Netherlands.

Design/Methodology - An exploratory approach rooted in a phenomenological perspective was followed. Two in-depth Interactive Qualitative Analysis (IQA) focus group sessions were held with a total of 21 self-initiated expatriate (SIE) women.

Findings - An integrated career development framework proposed in this study indicates that individual drivers such as identity, social support and life phase play a role in women's premigration and post-migration career success or exits. Identity embeddedness, host country culture, openness to foreigners and existing prejudices and stereotypes against women seems magnified for women from outside the host country.

Research Implications/Limitations - The research results may lack generalisability, therefore more research is encouraged to further test the proposed framework.

Practical Implications - Organisations should re-think existing systems for retaining highly skilled women migrants. Specific personnel management requirements and practical recommendations are provided for HR policy development with regard to migrant women.

Originality/value - An integrative approach and framework for understanding the career development decisions of professional and highly skilled migrant women who are also selfinitiated (SIE) is proposed. Insight is provided into the personal adjustment and professional developmental experiences of a group of women often overlooked by the research community.
\end{abstract}

Keywords Highly Skilled Migrant Professionals, Career Development, Women Career Success, Self-initiated Expatriate Women

Paper Type Research Paper 


\section{Introduction}

The aging workforce and declining population in Europe is increasing the need for talented employees who are willing and able to work. A study by Alphametrics (2005) stresses the implications of these changing demographics for both policy-makers and employers as the demand for talented, highly educated employees will continue to increase. Indeed, forecasts suggest that by 2018 there will be a general shortage of employees with high-level qualifications in Europe (Trinczek, 2010).

Women migrants and women self-initiated expatriates (SIEs) remain largely unseen and under-researched by the management community (McKenna and Richardson, 2007; Myers and Pringle, 2005; Vance, 2011). Little is known about their career-related behaviours and expectations (Al Ariss and Özbilgin, 2010; Biemann and Andresen, 2009). Vance (2011) emphasises the need to explore the role of having a local partner/spouse in the host country as a moderator for adding stability and support to the longer-term career track of a woman SIE. Iredale (2005) claims that this untapped talent pool of highly skilled, highly educated women professionals is largely neglected by local HR departments and policy-makers in host countries. These women could potentially form an essential resource in sustaining an organisation's competitive advantage and responding to the labour shortages posed by an aging population (Cole and McNulty, 2011).

The definition of a "migrant" provided by Mahraum (2002) is used to refer to the sample group in this paper - it is a broad definition encompassing both permanent and temporary international sojourners, including managers and executives, technicians, academics and scientists, entrepreneurs and students. In particular, this study sought to explore the experiences of "Western" migrants and self-directed expatriates in order to seek a basis for the comparison of experiences amongst them.

One country in Europe that underutilises women is the Netherlands, which lags behind the rest of Europe with regard to employing women in higher management positions, because many women in the Netherlands choose to work part-time, or interrupt their careers when they have children (Wüst, 2009). Despite the growing need for international talent (Cole and McNulty, 2011), gender stereotyping and discriminatory practices against women continue to erect barriers to women's career advancement (Wood, 2008). In addition, many organisations are reluctant to "praise and reward individuals" who pursue flexible career paths, such as protean or boundaryless careers, which are typically pursued by women (Volpe and Murphy, 2011, p. 62). 
The phenomenon of women opting out of a traditional career (leaving the workforce on a temporary or permanent basis) has been a point of interest in career research on women in their home countries (Volpe and Murphy, 2011), but this phenomenon has not yet been explored in the context of women living and working abroad for an extended period. Women who sojourn abroad of their own accord may be said to opt out of their pre-migration careers before continuing their career paths in their host countries. Apart from traditional barriers to returning to the workforce, the expatriation experience provides an extra layer of complexity to returning to the workforce (Tharmaseelan et al., 2010).

The purpose of this paper is to develop a conceptual framework for the understanding of especially the pre-migration and post-migration career development of women and to explore and interpret the career experiences of highly skilled professional women (SIEs and immigrants), with special reference to the Netherlands. In addition, the study aims to contribute to an understanding of the experiences of SIEs with spouses/partners in the host country in response to Vance's (2011) suggestions for further research.

\section{Background}

Forecasts indicate that the ageing population in the Netherlands, coupled with declining population growth, will lead to a situation where population growth from immigration will be higher than growth from natural births (Trinczek, 2010).

The Dutch government's vision is for the Netherlands to become one of the top five knowledge economies in the world (Van Oort and Raspe, 2005), which drives the aim to develop students with international savvy who will be able to work abroad and engage in international business activities (Mahraum, 2002), and, secondly, to attract international top talent through fiscal incentives for knowledge migrants (Dumont and Lemaittre, 2005). However, just as in other European countries (see, for example, Al Ariss, 2010), labour policies and practices still give preference to native employees and make it very difficult for employers to hire talent from outside the EU.

Furthermore, the official distinction that is made between Western and non-Western migrants (Merens et al., 2010), fosters the development of stereotypes and prejudices against foreigners which may pose further barriers to the career development and the availability of opportunities (Al Ariss, 2010). As a result, a psychological form of "brain waste" leads to the underutilisation of the human capital of foreigners (Tharmsaseelan et al, 2010, p. 233). 
The focus on migrant research in the Netherlands has been mainly on the so-called "nonWestern" immigrant, paying little attention to Western immigrants (it is assumed that Westerners will face less discrimination and fewer career barriers) and SIEs. However, the underrepresentation of women (both native and foreign) in the upper echelons gives rise to concern that gender discrimination may go beyond the country of origin (and in some cases, may be worse than in the country of origin).

\subsection{Organisational and Socio-political Barriers to Women Expatriates}

In the Netherlands more than three quarters of Dutch women participating in the workforce are only working part-time and are not economically independent, resulting in very few that reach the higher echelons in their organisations (Merens et al., 2010). Unlike their non-native counterparts, the majority of employed non-Western migrant women in the Netherlands pursue full-time careers (Merens et al., 2010). In some cases, non-Western migrants are leaving their Dutch counterparts behind, working up to 80 hours per week (Versluis, 2011). However, due to the exclusivity of career networks, many of these migrant women return to their home countries in order to achieve higher positions than they could in the Netherlands a phenomenon related to the "female brain drain" (Park, 2009). The Dutch government is considering implementing a quota system in all companies ensuring at least $30 \%$ of senior management and top positions are filled by women (Van der Kloor, 2009).

\subsection{Social Identity of Women and Career Success}

The "time-sequenced model" of migration and career success is one of a few initial attempts in the literature to gain an integrated understanding of the various predictors of career success during migration (Tharmaseelan et al., 2010). The strength of the model is its incorporation of both pre-migration and post-migration factors (internal and external) in determining career success. Unlike current thinking on boundaryless and protean careers (changeable and adaptable careers), this model assumes a degree of permanence in the migration process, the person's "career before migration" and the "career after migration".

Vance (2011) noted that women with international aspirations are more likely to opt for an SIE track than a company transfer. Current research on SIEs advocates the flexibility of this type of career path as a catalyst for women's career development (see, for example, Myers and Pringle, 2005; Vance, 2011). However, the literature on migration sketches a less rosy picture of the experiences of women who wish to pursue international careers. A study on Lebanese migrants in France, for example, found that career capital and self-initiated status was not helpful in career advancement (Al Ariss and Özbilgin, 2010). 
Volpe and Murphy (2011) developed a model for understanding why women exit their careers focusing on the influence of identity formation and social networks on women's career decisions. In the current study, we suggest that women who become international migrants inevitably have to opt out of their existing careers in their home country and re-build careers in the host country.

In order to understand women's career decisions, it is important to consider the drivers behind career success or career exits, in both the home country and host country, as moderated by factors during the pre-migration and post-migration career experiences. We propose a systemic framework that integrates and expands on the theoretical perspectives of Tharmaseelan et al. (2010) and Volpe and Murphy (2011) as a basis for understanding the international career development of professional women. Figure 1 illustrates a conceptual framework (developed by the authors of this study) of highly skilled migrant women's career barriers and support structures which formed the basis for the data analysis. 


\section{Figure 1.}

A conceptual framework of highly skilled migrant women's career barriers and support structures (Authors' own)

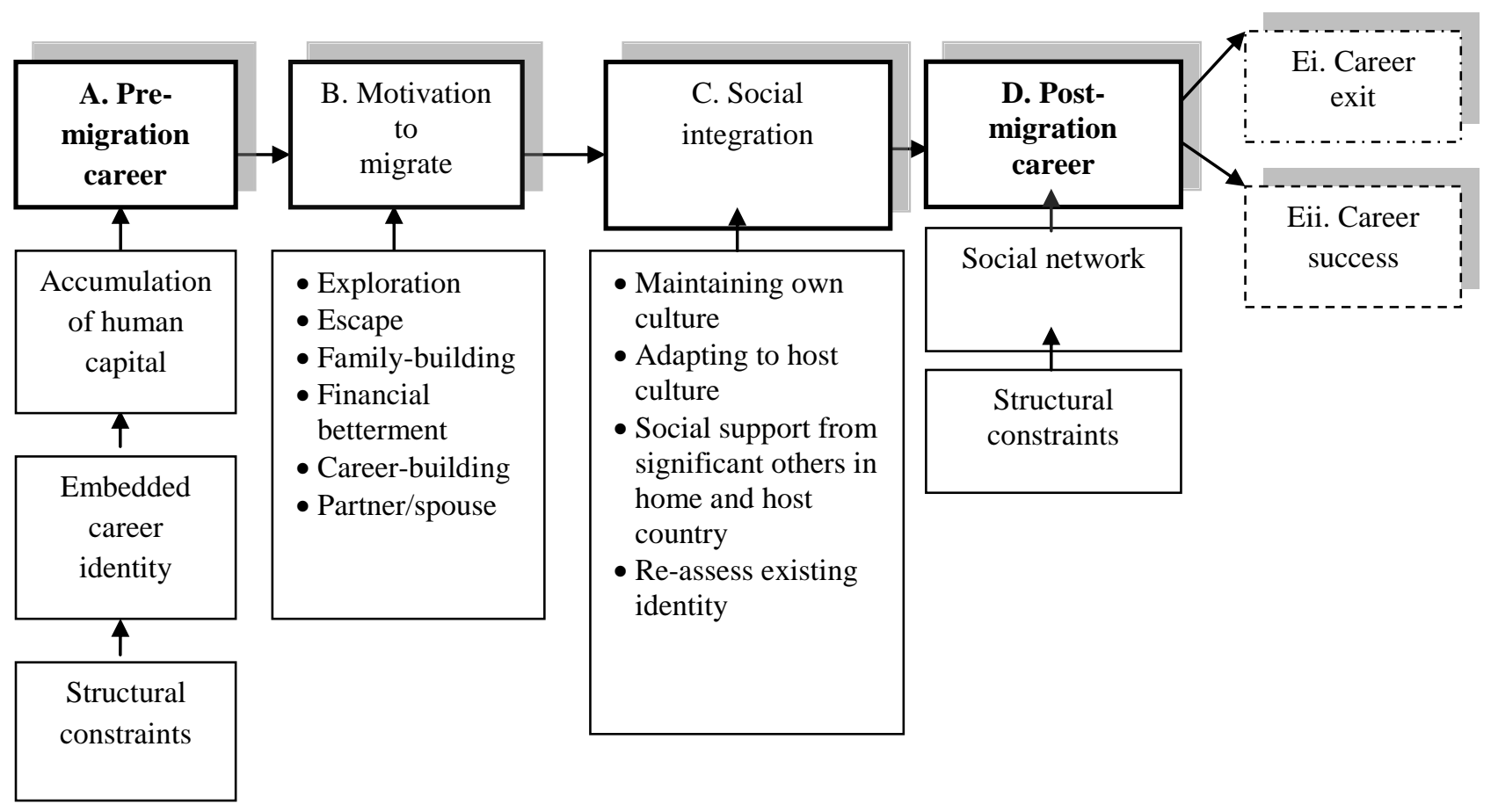

\section{A. The Pre-Migration Career}

The pre-migration career is defined by the accumulation of career capital which is acquired by a woman prior to migration, and which includes her education, work experience, knowledge and skills, and previous overseas experience (Tharmaseelan et al., 2010). Career capital accumulated outside the host country may not always be relevant or tradable in the host country (Al Ariss, 2010; Richardson and Mallon, 2005). Because women's career decisions are perhaps more influenced by factors such as non-work responsibilities, the needs of significant others and the fulfilment of personal values, the tradability of their acquired career capital may be even lower than that of their male counterparts (Cabrera, 2009; Myers and Pringle, 2005). Women's career choices prior to migration are also guided by their role identities as embedded in various social networks (Volpe and Murphy, 2011). Structural constraints in the home country may influence the options available to women and may include aspects such as the socio-political context, occupational and organisational demography and national culture (Volpe and Murphy, 2011). 


\section{B. Motivation to Migrate}

The findings by Tharmaseelan et al. (2010) indicate no predictive relationship between motivation perspective and career success. By contrast Cerdin et al. (2011) conclude that the motivation to migrate may have a significant influence on a person's level of adjustment, integration and career success in the host country. Some of the key motivators for migration include desire for exploration, escape, family building, financial betterment and career building (McKenna and Richardson, 2007; Tharmaseelan et al., 2010). Having a native host country partner/spouse may also significantly influence the decision to temporarily opt out of a career in order to establish a new career in the host country (Vance, 2005; Volpe and Murphy, 2011).

\section{Social Integration}

Encounters with new cultures may challenge a person's taken-for-granted self-concept and identity by calling existing mental and behavioural habits into question (Kim, 2001). Women's career decisions are strongly influenced by identity and sense of self, which is rooted in social relationships and networks (Richardson, 2006; Volpe and Murphy, 2011). Social support from significant others in the home and host country is essential for the positive reinforcement of role identity and in helping women re-build their professional identities. Social integration involves aspects such as the length of the women's stay in the host country, maintenance of their own culture, adaptation to the host culture, and social support from other foreigners and locals in the host country (Tharmaseelan et al., 2010). Research on the adjustment patterns of women has found that women expatriates tend to be better adjusted than their male counterparts (Selmer and Leung, 2003; Haslberger, 2010). Married SIEs also achieve better work outcomes than non-married SIEs (Selmer and Lauring, 2011).

\section{Post-Migration Career}

The traditional concept of a "career" as the property of an organisation has gradually shifted to a more protean or boundaryless conception where the individual takes responsibility for his/her own career (Stahl et al., 2002) and is able to exert a considerable amount of power and influence over his/her own career, and, in the case of SIEs, controlling the location of the career (Thorn, 2009). Although the decision to live and work abroad may be initiated by individual choice, there are multiple external factors influencing and often limiting the options 
available to the individual in the foreign setting (Richardson and Mallon, 2005; Bieman and Andresen, 2009; Park 2009). Tharmaseelan et al. (2010) emphasise the importance of proactive behaviour in ensuring career success such as career planning, networking, mentoring and education in the host country.

Networks can reinforce the career role identities for women in their local settings (Volpe and Murphy, 2011); where the long-term effects of a clearly defined identity embedded in a network of like-minded professionals will have a positive impact on the eventual career success of women migrants. Women with a local partner/spouse in the host country may achieve a higher level of career success because they have "inside access" to local networks and opportunities (Caliguiri and Lazarova, 2002; Osland, 2000).

Structural constraints affecting women's career decisions and eventual career paths such as organisational and occupational demography, socio-political context and the culture of the host country may pose significant limitations to the career paths of migrant women (Volpe and Murphy, 2011). Attitudes toward women, discrimination and stereotypes and prejudice may form further barriers to the success of migrants in the host country (Tharmaseelan et al., 2010), where women surrender themselves to a negative self-fulfilling prophecy ending in a negative spiral which may lead to their opting out (Wood, 2008).

\section{E. Post-Migration Career Exit/Post-Migration Career Success}

Career success is a multi-faceted concept that consists of overall career success, postmigration objective career success, and subjective career success (Tharmaseelan et al., 2010). Since traditional measures of career success are not relevant in evaluating protean career success, this study focused on subjective career success, which is defined as psychological success in terms of the fulfilment of personal values (Cabrera, 2009). Women tend to focus on the seamless integration of various interactions of their lives, and do not consider a "career" as a separate entity. The pursuit of a balance between their personal, work and family lives can also be considered a measure of career success for women (Myers and Pringle, 2005). Park (2009) therefore argues that organisations that wish to retain their professional female talent should help women achieve subjective career success and create opportunities for creating networks and knowledge sharing.

Post-migration career exiting may be related to aspects such as discrimination and segregation, exclusive staffing policies that do not provide many opportunities to foreigners and women, economic circumstances, or the fact that career capital obtained in the home 
country is not accepted as relevant in the host country (Al Ariss, 2010; Al Ariss and Özbilgin, 2010; Tharmaseelan et al., 2010; Volpe and Murphy, 2011).

\section{Research Methodology}

This exploratory study used an Interactive Qualitative Analysis (IQA) research design and process. IQA combines the tradition of phenomenology with systems theory (Sanchez, 2007). Northcutt and McCoy (2004, p. 40) link phenomenology and systems theory by describing social systems as "systems in which human interpretation of meaning is involved" - as is the case in this study. This approach is highly relevant to aiding our understanding of the career development of women, because structuring a career is also a system based on the way individuals shape, and are shaped by, their social contexts (Hartl, 2004, p. 42). According to Patton (1990, in Sanchez, 2007, p. 1240), the central question that systems theory aims to address is how and why a particular system functions as a whole.

Participants were recruited via the professional social networking site LinkedIn, using snowballing, and purposively selected by their biographical profile. A total of 21 highly skilled women migrants in the Netherlands, aged between 26 and 53, participated in the study.

Two focus groups were hosted in the Netherlands during the course of 2010. The first focus group consisted of 12 and the second group of 9 participants. The groups were large enough to generate interesting discussion, but small and intimate enough to provide a "safe" platform to explore relevant themes (Hartl, 2004, p. 42). Aliases were used in the final analysis of transcripts and company names were removed in discussions to protect identity. The demographics of the sample groups are illustrated in Table 1. 
Table 1.

Demographic overview of sample group

\begin{tabular}{|c|c|c|c|c|c|c|}
\hline & \multicolumn{6}{|c|}{ Focus Group 1} \\
\hline & Age & $\begin{array}{l}\text { Country } \\
\text { of Birth }\end{array}$ & $\begin{array}{l}\text { Pre- } \\
\text { migration } \\
\text { career }\end{array}$ & $\begin{array}{l}\text { Years in } \\
\text { the } \\
\text { Nether- } \\
\text { lands }\end{array}$ & Current Position & $\begin{array}{l}\text { Reason for } \\
\text { Expatriation/ } \\
\text { migration }\end{array}$ \\
\hline Adri & 27 & $\begin{array}{l}\text { South } \\
\text { Africa }\end{array}$ & $\begin{array}{l}\text { Post Graduate } \\
\text { Student }\end{array}$ & 7.5 years & Full time researcher, & $\begin{array}{l}\text { Career } \\
\text { building }\end{array}$ \\
\hline Annabelle & 28 & Romania & $\begin{array}{l}\text { University } \\
\text { Graduate }\end{array}$ & 4 years & Consultant & $\begin{array}{l}\text { Career } \\
\text { building }\end{array}$ \\
\hline Theresa & 36 & USA & $\begin{array}{l}\text { Relationship } \\
\text { marketing } \\
\text { manager }\end{array}$ & 8 years & Investment Manager & Exploration \\
\hline Michelle & 34 & $\begin{array}{l}\text { South } \\
\text { Africa }\end{array}$ & $\begin{array}{l}\text { Pattern maker } \\
\text { \& Designer }\end{array}$ & 1 year & $\begin{array}{l}\text { Freelance pattern cutter and } \\
\text { Designer }\end{array}$ & Dutch partner \\
\hline Bonita & 37 & USA & $\begin{array}{l}\text { Grants } \\
\text { Administrator }\end{array}$ & 4.5 months & $\begin{array}{l}\text { Unemployed } \\
\text { Seeking position }\end{array}$ & Dutch partner \\
\hline Sonja & 49 & Australia & Own business & 15 years & Own business & $\begin{array}{l}\text { Financial } \\
\text { betterment }\end{array}$ \\
\hline Jay & 26 & $\begin{array}{l}\text { South } \\
\text { Africa }\end{array}$ & $\begin{array}{l}\text { Development } \\
\text { worker in } \\
\text { India }\end{array}$ & 3 months & Au pair & $\begin{array}{l}\text { Financial } \\
\text { betterment }\end{array}$ \\
\hline Magdalena & 44 & $\begin{array}{l}\text { Ethiopia } \\
\text { (Italian } \\
\text { parents) }\end{array}$ & Own Business & 6 years & Own Business & $\begin{array}{l}\text { Family } \\
\text { building }\end{array}$ \\
\hline Inbal & 36 & Israel & $\begin{array}{l}\text { Office } \\
\text { manager }\end{array}$ & 2 years & HR Administrator & Dutch partner \\
\hline Rina & 26 & Romania & HR manager & $\begin{array}{l}1 \text { year and } \\
3 \text { months }\end{array}$ & HR Consultant & Dutch partner \\
\hline Sue & 53 & UK & $\begin{array}{l}\text { Own Business } \\
\text { Corporate } \\
\text { management } \\
\text { training }\end{array}$ & 14.5 years & $\begin{array}{l}\text { Freelance trainer and } \\
\text { lecturer }\end{array}$ & $\begin{array}{l}\text { Family } \\
\text { building }\end{array}$ \\
\hline Tatiana & 37 & Serbia & $\begin{array}{l}\text { Gestalt } \\
\text { Therapist }\end{array}$ & 4 years & $\begin{array}{l}\text { Own business, } \\
\text { Psychological Practice }\end{array}$ & Dutch partner \\
\hline
\end{tabular}




\begin{tabular}{|c|c|c|c|c|c|c|}
\hline & \multicolumn{6}{|c|}{ Focus Group 2} \\
\hline & Age & $\begin{array}{l}\text { Country } \\
\text { of Birth }\end{array}$ & $\begin{array}{l}\text { Pre-migration } \\
\text { career }\end{array}$ & $\begin{array}{l}\text { Years in } \\
\text { the } \\
\text { Nether- } \\
\text { lands }\end{array}$ & Current Position & $\begin{array}{l}\text { Reason for } \\
\text { Expatriation/ } \\
\text { migration }\end{array}$ \\
\hline Anushka & 48 & Russia & $\begin{array}{l}\text { Managing } \\
\text { Partner } \\
\text { (Financial } \\
\text { consulting } \\
\text { company) }\end{array}$ & 10 years & Senior Officer Finance & Dutch partner \\
\hline Bonnie & 27 & USA & Senior Auditor & $\begin{array}{l}6.5 \\
\text { months }\end{array}$ & $\begin{array}{l}\text { European Finance and } \\
\text { Accounting Manager }\end{array}$ & Exploration \\
\hline Sandra & 27 & Germany & $\begin{array}{l}\text { Event Manager, } \\
\text { Art Consulting, } \\
\text { Media System } \\
\text { Design }\end{array}$ & 7 months & Own Business & Exploration \\
\hline Maria & 28 & Spain & $\begin{array}{l}\text { Freelance } \\
\text { Translator }\end{array}$ & 2 years & Own Business & $\begin{array}{l}\text { Career } \\
\text { building }\end{array}$ \\
\hline Gina & 35 & Romania & $\begin{array}{l}\text { Financial } \\
\text { Controller }\end{array}$ & 4 years & $\begin{array}{l}\text { Senior Management } \\
\text { Accountant }\end{array}$ & $\begin{array}{l}\text { Family } \\
\text { Building }\end{array}$ \\
\hline Lana & 36 & $\begin{array}{l}\text { Czech } \\
\text { Republic }\end{array}$ & $\begin{array}{l}\text { Senior } \\
\text { Accountant }\end{array}$ & 10 years & Team Manager & Dutch partner \\
\hline Monika & 32 & Slovakia & Accountant & 11 years & Construction Professional & Exploration \\
\hline Tracy & 41 & $\begin{array}{l}\text { Hong } \\
\text { Kong }\end{array}$ & Social worker & 5 years & $\begin{array}{l}\text { Freelance Social Worker in } \\
\text { the Chinese community in } \\
\text { the Netherlands } \\
\text { (Tracy's qualifications are not } \\
\text { recognised in the Netherlands which } \\
\text { is why she opted to practice her } \\
\text { profession in an unofficial capacity) }\end{array}$ & Dutch partner \\
\hline Laura & 41 & Canada & Social Worker & 10 years & $\begin{array}{l}\text { Trainer/consultant } \\
\text { (Laura's qualifications are not } \\
\text { recognised in the Netherlands, } \\
\text { which is why she opted for a } \\
\text { different career path) }\end{array}$ & $\begin{array}{l}\text { Exploration } \\
\text { and Dutch } \\
\text { partner }\end{array}$ \\
\hline
\end{tabular}

\section{Data Collection}

Data was collected through two interactive focus group sessions by following the same protocol: Begin with a mental imagery warm-up exercise (brainstorming); then participants reflected silently on their experiences of living and working in the Netherlands and their professional migration experience. After the warm-up exercise, participants were asked to individually write down their thoughts, feelings and migration experiences on note cards which were shuffled and taped to a wall in the meeting room. All note cards, reflecting anything about their migration, were read out loud. After listening to the reflections, 
participants were invited to add any missing or additional thoughts, feelings and experiences on cards to the wall. The final set of cards set the agenda of themes for discussion and analysis.

\section{Data Analysis}

The focus group transcripts were subjected to Thematic Content Analysis (TCA) to identify emergent themes and their relationships (Anderson, 2007). Further in-depth analysis of data and comparison of emergent themes was done using the computer-assisted qualitative data analysis system Nvivo Xsight 2. A deductive approach was followed (Saunders et al., 2007, p. 488), using the conceptual framework developed and presented in Figure 1 to aid the analysis. Initial insights were gained into the potential utility and applicability of the framework on career development proposed in Figure 1.

\section{Findings}

Findings are reported in line with Figure 1, citing individual responses to illustrate the various aspects of the proposed framework.

\subsection{Pre-Migration Career (Refer to Figure 1, Part A)}

The important aspects of pre-migration career per our framework are the career capital and skills obtained prior to relocation to the host country, the embedded career identity as formed by significant others, social networks that contribute to identity formation and career success in the home country and structural constraints for women who want to pursue careers in the home country.

\subsubsection{Career Capital/Skills}

Previous experience in a foreign country was one of the most important themes that influenced participants' choices in opting for international mobility at later stages in their lives. Inbal and Sonja both spent a significant part of their childhoods in the United States. Growing up across cultures and continents helped them gain competencies needed for pursuing an international lifestyle, awakening needs that could not be satisfied by remaining in their home countries.

Participants in their mid- to late 20s felt that multiple international experiences left them with a sense of displacement and uncertainty. The question of whether they would 
continue to "jump" from country to country and remain a foreigner for life, or return to their home countries was a key question. The foreign experience brings with it the possibility of seeking wider horizons, but also leads to the difficult dilemma of returning "home", the questions of "what/where is home?" and "who am I?"

\subsubsection{Embedded Career Identity}

Participants from former Eastern European countries emphasised the role of equality in gender socialisation and career development. They valued their career development and voiced a strong drive for success. The equal role of women in society and the business world was not something to be questioned, but an accepted fact which afforded the opportunity to grow and develop one's career without any limitations. Growing into management positions was completely acceptable. Anushka (Russia) said that in Russia "women play a great role...If you are a manager of a company it's fine".

Being treated as equal and afforded equal opportunities in different sectors reinforced participants' sense of self and career identity to allow them to achieve their career goals: "I try to think that I am equal and that because I'm in a man's world, I'm a woman and I reached a good position... it was something that came very easily.” (Gina, Romania)

Feeling rooted and having strong support from parents, friends and family members helps participants shape their careers and feel confident in their abilities. Interestingly, rootedness had different meanings for the younger participants, who emphasised country and culture as components of stability. For women in the 35 to 40 year range, rootedness was embedded in social networks and their careers in their home countries - they knew who they were and were sure of what they wanted from life and their careers. Two participants commented as follows: "I was very confident, very together...I knew where I was in my life...everything was...established and I was fine tuned." (Bonita, USA)

"Back home I had a great job and a very active social life...." (Inbal, Israel)

Sue (UK) had an especially difficult time in adjusting to life in the Netherlands and refers to her "life before" and her current life: "[T]he life that I had before...was wonderful... good friends...doing well in my work... my child was happy...things were going really well...I truly believed that I was good at my job and other people seemed to support that view. I believed I had something to offer."

Having social support structures at work and at home helped to reinforce women's sense of self and confidence in their ability to succeed. 


\subsubsection{Structural Constraints}

There were mixed responses in terms of structural constraints. The socio-political and legal situations in the home country were determinants of the career options available to women. For example, paying for childcare and domestic help enabled women in some countries to pursue professional full-time careers, whilst others felt that flexible work arrangements were a blessing for mothers who would otherwise have to stop work completely.

\subsection{Motivation to Migrate (Refer to Figure 1, Part B)}

The majority of the women who participated in this study decided to migrate to the Netherlands to explore or join their Dutch spouses. It is important to note that although the motivation for this migration decision may have been based on family reasons, these women also lived and worked abroad for their professional careers. They are seasoned travellers whose previous international moves were motivated by their jobs. This study provides only a snapshot of the very complex and varied nature of the motivations behind the career decisions of professional women. The motivation to migrate is also related to the level of status ascribed to participants and consequent structural barriers to entry. Being the partner of a Dutch citizen made participants feel that they were perceived as less capable than expatriate transferees. It also had a significant impact on their levels of self-esteem and sense of identity: "For me coming here was an intrinsic choice. Before coming here, my moving choices were based on career, and this time it was based on a man and it felt wrong for a long time." (Rina, Romania)

\subsection{Social Integration (Refer to Figure 1, Part C)}

Four themes emerged as important drivers to support or hamper the social integration experienced by participants: maintaining their own culture, adapting to the host culture, social support and reassessing an existing identity.

\subsubsection{Maintaining Their Own Culture}

The process of changing from one orientation to another can be selective, implying that individuals have a choice about which elements of their own culture they wish to surrender and which elements of the new culture they wish to incorporate into their existing repertoire (Padilla and Perez, 2003). Maintaining one's own culture implies remaining true to oneself 
and the values that one grew up with. Adjustment is a continuous process of navigating one's cultural identity and setting clear boundaries. Participants commented as follows:

"I would like to be who I am... I am willing to integrate and adapt...change some things but not all." (Inbal, Israel)

"...there were certain aspects of me...I really wanted to keep...that...I decided which part of the ... culture I did want to become part of." (Sue, UK)

“... what do I take...what do I like...what is the limit..." (Magdalena, Ethiopia)

\subsubsection{Adapting to the Host Culture}

The process of adjustment to the host country was considered a vital part of living and working in an international context. Learning to change one's point of view and being able to expand one's repertoire of values and behaviours is a reward associated with an international lifestyle. Clinging to one's own culture and values whilst continuously longing for things in the home country was considered counterproductive and even a bit "dangerous", as Maria (Spain) noted: “[Maintaining one's own culture] can also be a bit dangerous...either you embrace it, or you just go back home...."

However, arriving at a point of accepting the host culture and becoming effective in the host society is not a simple once-off event. It is a continuous process that affects all spheres of life: "It's a big shift and it takes time. It's a process and I think I just couldn't prepare for that ... I knew that it would be difficult...I didn't know how...constantly and how long!" (Bonita, USA).

“...It's a revolution in values...” (Magdalena, Ethiopia)

The adjustment process also had a significant influence on identity. Inbal (Israel) summarised the adaptation process as follows: "If you want to become fully adapted, you lose a little bit of who you really are."

\subsubsection{Social Support}

Not surprisingly, participants emphasised the value of strong social support networks from locals, the international community and family in the home country. However, a surprising finding was that women in the group actually had more frequent contact with loved ones in their home country. Busy schedules and frequent travel meant that they had little or no interaction with their local support networks while they were living in their home countries. 
Social media and VOIP technology such as Skype have enabled them to manage their relations with their loved ones despite the distance:

"I can talk to my mom every couple of days." (Bonita, USA)

"I speak to my mom more than when I was living in my own country." (Rina, Romania)

\subsubsection{Re-assessing Existing Identity}

Participants found that they needed to re-assess who they felt they were, but found that the demands of the situation did not always give them the opportunity:

"The practicalities of life are overwhelming and takes up all your energy... don't have ...energy and time to think about...work, identity and self-esteem.” (Bonita, USA)

Those who decided to migrate to the Netherlands to be with their Dutch partners found it more difficult. For these women, living abroad was a highly emotional and complex journey of reinvention and self-discovery. The choice of moving to the Netherlands brought with it so many choices that participants felt trapped and overwhelmed by the sheer number of choices they had to make in a short time. Although choice seemed to be a barrier for some participants, others saw coming to the Netherlands as bringing new choices and new freedom in choosing, a positive experience that allows for growth, development and reinvention:

"It is a choice to become what you want to become..." (Sonja, Australia)

\subsection{Post-Migration Career (Refer to Figure 1, Part D)}

The career choices and opportunities available to women after their migration are often influenced by structures beyond the individual's control.

\subsubsection{Structural Constraints}

Structural constraints are the external environmental influences on the career over which women have little or no control. This includes aspects such as language, male dominated culture, attitudes toward foreigners, networking, mentors and career counsellors, and making sure that one is recognised.

\subsubsection{Language}

Mastering the language at a professional level proved to be a major challenge for participants, a challenge that was often associated with unrealistic expectations from their colleagues and 
employers. A lot of effort is put into learning the language and becoming fluent, but they encountered a number of barriers.

Firstly, participants indicated the unrealistic expectations of their colleagues and employers with regards to learning Dutch:

“...after 6 months or a year of learning Dutch you will not...go...to work and speak fluent Dutch...There is a sort of impatience..." (Gina, Romania)

“...after a few weeks they expected me to speak Dutch fluently." (Annabelle, Romania)

Anushka (Russia) also had negative experiences regarding language in the business environment. Despite her efforts to learn the language and perfect her accent, she was still labelled a foreigner and consequently treated as someone whose language was unintelligible: “In business life I still come across people who say that they don't understand me...doesn't matter that you speak Dutch and understand everything, you are still a foreigner."

Negative feedback from Dutch colleagues led to a sense of despair and in some cases even made some women decide to stop learning the language altogether.

\subsubsection{Male-Dominated Culture}

Participants indicated that women in the Netherlands face considerable barriers in terms of gender stereotyping. For women, not belonging to the "old boys' network" and not being a Dutch national (who seem to get more support than international colleagues) were major barriers to promotional opportunities:

“...give me support.... As much as you would support...Dutch nationals. ...it's Dutch boys...I often felt...discrimination there." (Gina, Romania)

“...this is the 'boys club'...it's like 'hahahaha' you know, we' re the men." (Bonny, USA)

It seems that many companies and industries do not respect the authority of women, let alone women from abroad, as Anushka (Russia) found: "My manager...told me: 'I' $m$ very surprised that ... Russian men were talking to you. They take you seriously.' And I asked why they shouldn't take me seriously, and he said 'because you're a woman.' It was ... the first time I've been rejected by the company because they wanted only men to be part of the conversation."

\subsubsection{Attitudes toward Foreigners}


The current discourse in the Netherlands around foreigners seems to reinforce stereotypes and prejudice towards foreigners, as Gina (Romania) noted: “...openness to immigrants... in the past there was...genuine curiosity about people from other countries... they've been bombarded by a lot of other people coming, [which makes] them more closed."

Participants agreed that their "foreigner" status (regardless of country of origin) significantly hampered their career options. In both groups, participants indicated the reluctance of employers to provide fixed contracts to foreigners despite their high level of skills.

Anushka's experience of discrimination further explicates the general animosity towards foreigners held by recruiters: "He...told me: 'You know, I never met such an animal as the Soviet Union people... I'd like to see you in person.' ... He was finance manager [at a] very big international recruitment company...I asked him about discrimination and he said, '...Just now I had...3 candidates. One was excellent...from the Turkish region...The second was French, more or less acceptable...the last was Dutch...he was absolutely unacceptable... who do you think they chose for the job? They chose the Dutch person."' (Anushka, Russia)

\subsubsection{Networking}

Networking includes associating oneself with the right people and finding mentors and career counsellors who can provide guidance towards career success. It also includes the individual activities that women engage in to make sure that their talents are recognised in the workplace to ensure upward mobility.

\subsubsection{Mentors and Career Counsellors}

Finding someone who can help one understand one's own competencies and who can provide positive reinforcement to career identity emerged as an important support factor in the success or failure of women's post-migration career, as Magdalena (Ethiopia) pointed out: “...you first need information...to understand yourself and know where you want to go so that you are allowed to go where you want to be."

\subsubsection{Making Sure that You Are Recognised}


It seems that the barriers women were facing in achieving career success served as a motivator to increase their determination to achieve success, proving that against all odds one can and will be successful by setting oneself apart:

“You have to execute... If you don't fight for it...making sure, 'hey, I'm here amongst all the others." (Monika, Slovakia)

"We have to prove ourselves... I had to prove myself that I was there." (Maria, Spain)

"You have to show them that you are good at what you do." (Annabelle, Romania)

\subsection{Career Exit or Career Success (Refer to Figure 1, Part Ei \& Eii)}

The post-migration career can result in either career exit or career success.

Participants who opted out of their careers after migration indicated that their choices were influenced by the burden of care and household responsibilities. The Dutch system traditionally assumes a breadwinner model where the mother stays at home to take care of the children. As a result, childcare is very expensive and school activities are built around the fact that mothers are at home to support their children. For many women with children, it is consequently impossible to pursue formal employment, as was the case for Magdalena (Ethiopia) and Sonja (Australia) who both opted for a more flexible entrepreneurial route.

Sue (UK) also ended opting out of her career whilst in the Netherlands after unsuccessfully trying to set up her own business. In her case, a severe identity crisis and her inability to regain her self-confidence through supportive networks drove her to settle for a freelance career: "That is where I came unstuck here when I set up a business from scratch... did not have the courage to branch out, to network and cold call...I gradually lost heart...I lacked courage and am very disappointed in myself."

\section{Conclusions and Recommendations}

This study aimed to contribute to the current discourse about the career development and opportunities for highly skilled women as migrants with special reference to the Netherlands.

We recognise that findings in this paper correspond with previous research on expatriate acculturation (Iredale, 2005:165; Al Ariss and Özbilgin, 2010:278). However, aspects such as status and identity seem to be significant moderators for women who decide to migrate for family-building reasons. The fact that women opt out of existing professional careers for their spouses/partners in the host country seems to automatically place them in a lower status 
category than their company transferred counterparts (Lee, et.al, 2009). The role of language in the expression of identity is of specific interest, especially considering the fact that women's career choices are much more strongly influenced by their identity development than their male counterparts (Shortland, 2009).

A theme that emerged from this study which has not yet been explored in the expatriate research is the role of age and life phase development on the international career development of women. For younger women, the crisis of establishing a clear identity that is rooted in either the host country (being a foreigner for life) or the home country (where these women may no longer fit in any longer) significantly influences their career choices. Older women in the 35 to 40 year age group who have already established a career identity that is embedded in their home country's social networks may find themselves at a double crossroads when opting to move abroad to join a partner or spouse.

Moving to another country means that these women not only have to re-establish their lives in terms of general practicalities, they also have to replace life-long support structures that no longer exist. Thus in a life phase during which a woman would usually seek stability and rootedness, she has to start rebuilding herself. Despite the relative confidence and success that participants experienced prior to their expatriation, adaptation to the host country has had a big influence on the further identity formation and self-esteem of formerly successful professionals. Existing feelings of uncertainty may be worsened by external barriers and a lack of positive reinforcement.

A major theoretical contribution of this study is the resultant integrative, conceptual preand post-migration framework for understanding the possible factors influencing the career development and success for professional women migrants. Despite the relative confidence and success that participants experienced prior to their expatriation, adaptation to the host country has had a big influence on the further identity formation and self-esteem of formerly successful professionals. Existing feelings of uncertainty may be worsened by external barriers and a lack of positive reinforcement.

On a practical level the value of this study is especially significant for recruiters and HR policy makers. Considering the high level of motivation and drive for achievement of women migrants (and their willingness to do what it takes to get to the top) provides an alternative source of diverse talent - a gap that many Dutch women (who prefer to work part time) would prefer not to fill. Recruiters should be aware of the fact that high potential talent may be ignored due to the impact of early adjustment experiences and identity crisis on women's 
performance on competency assessments. There is a need to re-assess the current thinking of careers and what they mean for women, in order to leverage the unique strengths they bring into the workplace. Women should be supported in establishing their career identities in the host country by educating managers and helping the women to re-frame their expectations of subjective career success. Career counsellors and mentors (both male and female) could play a critical role in helping women develop strong and embedded career identities in the host country (Volpe and Murphy, 2011).

The value of this study is the development of an integrative approach and framework for understanding the career development decisions of professional and highly skilled migrant women who are also self-initiated (SIE). Furthermore, insight is provided into the personal adjustment and professional developmental experiences, as per framework, of this under researched group of women whose career development is growing in importance in a turbulent global economic environment where talent is sought. This research can be especially linked to the emergence of Work-family life patterns for women from different cultures as well as the crucial role that identity construction and coping strategies play in the adjustment of SIE women. These themes have not yet been explored by the management research community.

\section{Limitations and Further Studies Suggested}

Given the small sample size, the generalisability of the findings is limited and needs to be further explored in other countries. This paper aims to initiate further discourse and research to validate the framework provided and to strengthen the theoretical underpinnings of these findings. The challenges faced by the women (both from Western and Eastern European countries) in this study suggest the need for further investigation of the complex factors that influence migrant women's career success in the host country. We also suggest a further exploration of the impact of migration on the life phases and career development of professional women. 


\section{References}

Alphametrics (2005), "The implications of demographic trends for employment and jobs", available at: http://www.mature-project.eu/materials/lot2_occupations_summary_en.pdf (accessed 12 March 2011).

Al Ariss, A. (2010), "Modes of engagement: migration, self-initiated expatriation, and career development", Career Development International, Vol. 15, No. 4, pp. 338-358.

Al Ariss, A. and Özbilgin, M. (2010), "Understanding self-initiated expatriates: career experiences of Lebanese self-initiated expatriates in France", Thunderbird International Business Review, Vol. 53, no. 4, pp. 275-285.

Biemann, T. and Andresen, M. (2009), "Self-initiated foreign expatriates versus assigned expatriates - two distinct types of international careers?", Journal of Managerial Psychology, Vol. 25, No. 4, pp. 430-448.

Cabrera, E.F., (2008), "Protean organizations. Reshaping work and careers to retain female talent", Career Development International, Vol. 15, No. 2, pp. 186-201.

Caliguiri, P. \& Lazarova, M. (2002), “A model for the influence of social interaction and social support on female expatriates' cross-cultural adjustment", International Journal of Human Resource Management, Vol.13, No. 5, pp. 761-772.

Cerdin, J.L., Dine, M.A. and Brewster, C. (2011), “Qualified immigrant's success: exploring the motivation to migrate and to adjust," Paper presented at the annual conference of the European Academy of Management, June, Tallinn.

Cole, N. and Mc Nulty, Y. (2011), "Why do female expatriates 'fit in' better than males? An analysis of self-transcendence and socio-cultural adjustment," Cross Cultural Management: An International Journal. Vol. 19, No.2, pp. 144-164.

Dumont, J.C., and Lemaître, G. (2005), "Counting immigrants and expatriates in OECD countries: a new perspective", paper presented at United Nations Expert Group Meeting on International Migration and Development, 6-8 July, New York, NY, available at: http://www.oecd.org/dataoecd/27/5/33868740.pdf (accessed 7 March 2011).

Hartl, K. (2004), “The expatriate career transition and women managers' experiences", Women in Management Review, Vol. 19, No. 1, pp. 40-51.

Haslberger, A. (2010), “Gender differences in expatriate adjustment”, European Journal of International Management, Vol. 4, No. 1/2, pp. 163-183. 
Haupt, A. and Janeba, E. (2009), "Education, redistribution and the threat of brain drain", International Journal of Tax \& Public Finance, Vol. 16, pp. 1-24.

Iredale, R. (2005), "Gender immigration policies and accreditation: valuing the skills of professional women migrants", Geoforum, Vol. 36, pp.155-166.

Kim, Y.Y. (2001), Becoming intercultural: an integrative theory of communication and crosscultural adaptation. Thousand Oaks, CA: Sage.

Lee, J., Toney, M.B. and Berry, E.H. (2009), "Social status inconsistency and migration”, Research in Social Stratification and Mobility, Vol. 27, pp. 35-49.

Mahraum, S. (2002), "Highly skilled globetrotters: mapping the international migration of human capital", $R \&$ D Management, Vol. 30, No. 1, pp. 23-31.

Mc Kenna, S. and Richardson, J. (2007), "The increasing complexity of the internationally mobile professional - issues for research and practice", Cross Cultural Management, Vol. 14, No. 4, pp. 307-320.

Merens, A., Van den Brakel, M. and Hartgers, M. (2010), “Emancipatiemonitor 2010”, Sociaal en Cultureel Planbureau, Den Haag, available at http://www.cbs.nl/NR/rdonlyres/807269BC-325D-4DEB-AC8A-

A9C70BAF206B/0/emancipatiemonitor2010.pdf (accessed 19 July 2011).

Myers, B. and Pringle, J.K. (2005), "Self-initiated foreign experience as accelerated development: influences of gender", Journal of World Business, Vol. 40, pp. 421-431.

Northcutt, N. and McCoy, D. (2004), IQA: A Systems Method for Qualitative Research, Sage, London.

Osland, J.S. (2000), "The journey inward: expatriate hero tales and paradoxes", Human Resource Management, Vol. 39, No’s 2 \& 3, pp. 227-238.

Padilla, A.M. \& Perez, W. (2003), “Acculturation, Social Identity, and Social Cognition: A New Perspective”, Hispanic Journal of Behavioural Sciences, Vol. 25, No. 1, pp. 35-55.

Park, Y., (2009), "Factors influencing self-directed career management: an integrative investigation”, Journal of European Industrial Training, Vol. 33, No. 7, pp. 578-593.

Richardson, J. (2006), “Self-directed expatriation: family matters”, Personnel Review, Vol. 35, No. 4, pp.469-486.

Richardson, J. and Mallon, M. (2005), "Career interrupted? The case of the self-directed expatriate", Journal of World Business, Vol. 40, pp.409-420.

Saunders, M.N.K., Lewis, P. and Thornhill, A. (2007), Research Methods for Business Students, 4th edition, Essex: Pearson. 
Sanchez, J. (2007), "Second life: an interactive qualitative analysis", in Crawford, C. D.A. Willis, R., Carlsen, I. Gibson, K. McFerrin, J. Price, and R. Weber R. (Eds.), Proceedings of Society for Information Technology and Teacher Education International Conference 2007, AACE, Chesapeake, VA, pp. 1240-1243.

Selmer, J. and Lauring, J. (2011), "Marital status and work outcomes of self-initiated expatriates. Is there a moderating effect of gender?" Cross Cultural Management: An international Journal, Vol. 18, No. 2, pp. 198-213.

Selmer, J. \& Leung, A.S.M. (2003), "Expatriate career intentions of women on foreign assignments and their adjustment", Journal of Managerial Psychology, Vol.18, No.3, pp.244-258. [Online] Available From: Emerald Insight: http://www.emeraldinsight.com/0268-3946.htm [Downloaded: 2009-03-31].

Shortland, S. (2009), "Gender diversity in expatriation: evaluating theoretical perspectives", Gender in Management: An International Journal, Vol. 24, No. 5, pp. 365-386.

Stahl, G.K., Miller, E.L. and Tung, R.L. (2002), "Toward the boundaryless career: a closer look at the expatriate career concept and the perceived implications of an international assignment", Journal of World Business, Vol. 37, pp. 216-227.

Tharmaseelan, N., Inkson, K., and Carr, S.C (2010), "Migration and career success: testing a time-sequenced model”, Career Development International, Vol. 15, No. 3, 219-238.

Thorn, K. (2009), "The relative importance of motives for international self-initiated mobility", Career Development International, Vol. 14, No.5, pp. 441-464.

Trinczek, R. (2010), "Demographic change and work in Europe", European Foundation for the improvement of living and working conditions, 16 December, available at: https://eurofound.europa.eu/ewco/surveyreports/EU0902019D/EU0902019D.htm (accessed 12 March 2011).

Unknown Author, (2011), "Hoofdlijnen emancipatiebeleid: vrouwen- en homo-emancipatie 2011-2015", Kamerstuk: Kamerbrief, 08 April, available at: http://www.rijksoverheid.nl/documenten-en-

publicaties/kamerstukken/2011/04/08/hoofdlijnen-emancipatiebeleid---vrouwen--enhomo-emancipatie-2011-2015.html (accessed 25 July 2011).

Vance, C.M. (2011), “A comparison of female and male strategies for securing and enduring expatriate career development experiences", Paper presented at the annual meeting of the European Academy of Management, June, Tallinn, Estonia. 
Van der Kloor, R. (2009), "Kamer eist quotum voor "vrouwen aan de top"”, Elsevier, 26 October, available at: http://www.elsevier.nl/web/Nieuws/Nederland/249216/Kamereist-quotum-voor-vrouwen-aan-de-top.htm (accessed 12 March 2011).

Van Oort, F.G. and Raspe, O. (2005), “The knowledge economy and Dutch cities", paper presented at European Regional Science conference (ERSA), 23 - 27 August, Amsterdam, available at: $\underline{\text { http://www-sre.wu- }}$ wien.ac.at/ersa/ersaconfs/ersa05/papers/165.pdf (accessed 7 March 2011).

Versluis, K. (2011), "Hoe allochtonen vrouwen het bedrijfsleven bestormen...terwijl hun broers mislukken", Intermediair, 5 May, available at:

http://www.intermediair.nl/artikel/diversiteit/242823/hoe-allochtone-vrouwen-hetbedrijfsleven-bestormen.html (accessed 20 July 2011).

Volpe, E.H., and Murphy, W. M. (2011). "Married professional women's career exit: integrating identity and social networks", Gender in Management: An international Journal, Vol. 26, No.1, pp. 57-83.

Welman, J.C. and Kruger, S.J. (1999), Research Methodology for the Business and Administrative Sciences, Thompson International, Johannesburg, South Africa.

Wood, G. (2008), “Gender stereotypical attitudes. Past, present and future influences on women's career advancement", Equal Opportunities International, Vol. 27, No.7, pp. 613-628.

Wüst, D. (2009), "Vrouwen aan de top: Nederland blijft slecht scoren”, VK Banen, 6 March, available at: http://www.vkbanen.nl/banen/artikel/Vrouwen-aan-de-top-Nederlandblijft-slecht-scoren/98910.html (accessed 12 March 2011). 


\section{Figure 1.}

A conceptual framework of highly skilled migrant women's career barriers and support structures (Authors' own)

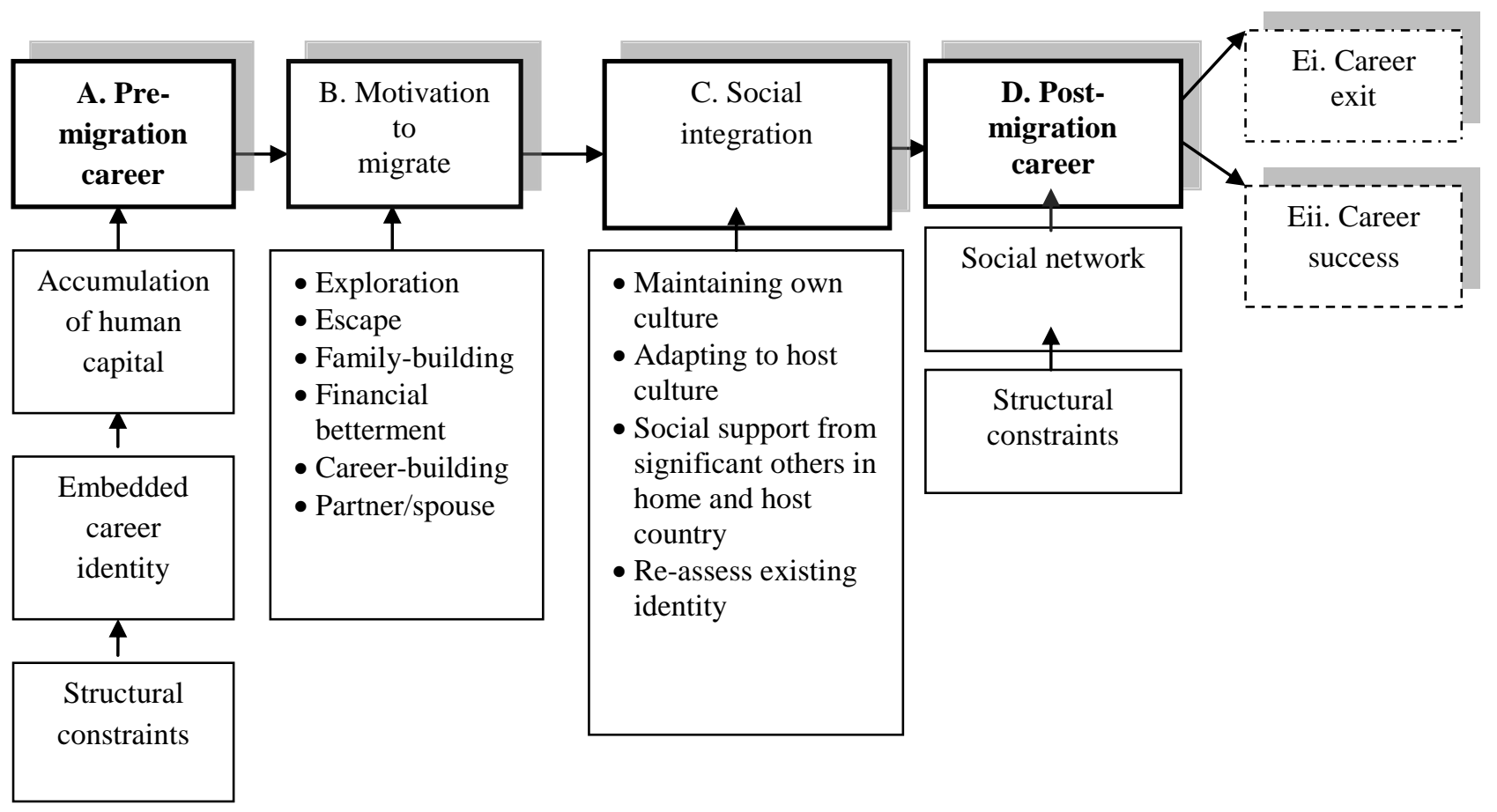

